\title{
Kelimpahan, Biologi, dan Kemampuan Pemangsaan Oligota sp. (Coleoptera: Staphylinidae), Kumbang Predator Tungau pada Tanaman Ubikayu
}

(Abundance, Biology, and Predation Ability of Oligota sp. (Coleoptera: Staphylinidae), Mites-Predatory Beetle on Cassava)

\author{
Widyantoro Cahyo Setiawan $^{1}$, dan Sugeng Santoso ${ }^{1 *}$ \\ ${ }^{1}$ Departemen Proteksi Tanaman, Fakultas Pertanian, Institut Pertanian Bogor \\ Jl. Kamper, Kampus IPB Dramaga, Bogor, Indonesia, 16680 \\ *Email Korespondensi: ssantoso@apps.ipb.ac.id
}

Diterima 25 Maret 2019/Disetujui 10 Mei 2019

\begin{abstract}
Mites infestation is one of the main problem in many agricultural commodities. One of the best methods to control mites infestation is biological control using insect predators. The objective of this study is to know the abundance, biology, and predation ability of mites-predatory beetle, Oligota sp. on cassava. Surveys were conducted in cassava plantation around Bogor to know the abundance of Oligota sp. Oligota sp. collected from the field were reared in the laboratory to observe its biology. Experiment to know the predation ability of Oligota sp. was conducted using $3^{\text {rd }}$ stage larvae, with 5, 10, 15, 20, and 25 adult mites as preys. Observations were carried out 3, 6 and 24 hours after treatment. The developmental time of male and female were 15.047 and 16.097 days, respectively. The longevity of male and female were 20.974 and 21.677 days respectively. Female laid 22.923 eggs in 14.154 days. The $3^{\text {rd }}$ stage larva of Oligota sp. consumed 18 adult mites for 24 hours.
\end{abstract}

Keywords: abundance, biology, predatory beetle, mite.

\section{ABSTRAK}

Pengendalian hayati dilakukan untuk mengendalikan tungau salah satunya dengan agen hayati seperti serangga predator. Penelitian ini bertujuan memberikan informasi tentang kelimpahan, biologi, dan potensi pemangsaan kumbang predator tungau Oligota sp. pada tanaman ubi kayu. Tungau dan kumbang Oligota sp. yang diperoleh dilapang dipelihara sampai menghasilkan telur dan diamati setiap perkembangan stadianya. Pengujian predasi kumbang predator dilakukan menggunakan larva instar 3 kumbang Oligota sp. dengan cara dimasukkan kedalam cawan dan diberi tungau dengan perlakuan sebanyak 5, 10, 15, 20, dan 25 imago tungau. Pengamatan dilakukan selama 3 jam, 6 jam, dan 24 jam dilakukan dengan 10 kali ulangan. Kumbang ini memiliki siklus hidup dari telur sampai mati pada imago jantan rata-rata selama 36.021 hari, sedangkan betina 37.774 hari. Rata-rata dari telur yang dihasilkan semua pasangan sebanyak 22.923 telur. Kumbang Oligota sp. memiliki kemampuan predasi memangsa tungau dalam sehari rata-rata sebanyak 18 ekor. Predator tungau yang paling banyak ditemukan dilapang yaitu tungau predator.

Kata kunci: biologi, kelimpahan, kumbang predator, tungau.

\section{PENDAHULUAN}

Ubikayu (Manihot utilissima) merupakan salah satu komoditas pangan penting bagi negara beriklim tropis seperti Nigeria, Brazil, Thailand, dan Indonesia. Keempat negara tersebut merupakan negara penghasil ubikayu terbesar di dunia. Di Indonesia, ubikayu menjadi salah satu tanaman yang banyak ditanam hampir di seluruh wilayah. Sebagian masyarakat Indonesia menjadikannya sebagai bahan makanan pokok yang mengandung sumber karbohidrat utama setelah beras dan jagung. Sebagian besar produksi ubikayu di Indonesia digunakan untuk memenuhi kebutuhan dalam negeri $(85-90 \%)$ sedangkan sisanya diekspor (Hafsah 2003).
Berdasarkan data Badan Pusat Statistik (2012) produksi ubikayu di Indonesia mengalami penurunan tercatat pada tahun 2011 produksi ubikayu mencapai 240 juta ton sedangkan pada tahun 2012 hanya 226 juta ton. Penurunan produktivitas mengindikasikan adanya kendala dalam budidaya ubikayu. Kendala tersebut dapat berasal dari aspek budidaya, iklim, maupun hama penyakit tanaman yang menyerang tanaman ubikayu.

Tungau merah (Tetranychus kanzawai) merupakan salah satu hama penting yang menyerang tanaman ubikayu dan dapat menyebabkan kerugian. Serangan tungau meningkat pada musim kemarau menyebabkan rontoknya daun dan tanaman ubikayu seperti mengeras dan tumbuhnya tunas-tunas baru pada setiap ketiak daun. Penurunan hasil akibat serangan hama ini dapat mencapai 20 sampai 53\%, 
bahkan hingga $95 \%$ pada serangan berat (Kusumastuti 2007). Tungau merah merupakan hama yang penting pada berbagai tanaman pertanian dan paling banyak terdapat di Asia Timur, meskipun sekarang sudah diamati di seluruh dunia termasuk Asia Tenggara, Oceania dan Amerika Utara.

Pengendalian hayati merupakan salah satu pengendalian dengan memanfaatkan agen hayati. Jenis agen hayati diantaranya serangga, cendawan, bakteri, nematoda, dan virus. Agen hayati tersebut sebagai musuh alami organisme pengganggu tanaman (OPT). Salah satunya dengan memanfaatkan serangga yang bersifat predator sebagai pengendali. Kumbang Oligota sp. (Coleoptera: Staphylinidae) merupakan salah satu kumbang predator yang memiliki potensi dalam memangsa tungau. Hal tersebut karena stadia larva dan imago dari kumbang ini menjadikan tungau sebagai mangsanya.

Menurut penelitian Chazeau (1985) predator Oligota sp. pada tahapan perkembangan memangsa tungau sebanyak 20 ekor per hari dan pada tahapan dewasa atau imago memangsa tungau 10 ekor per hari.

Penelitian ini diharapkan mampu memberikan informasi tentang biologi dan kelimpahan kumbang predator tungau pada tanaman ubi kayu yang potensial untuk dimanfaatkan sebagai agens pengendalian hayati di lapangan.

\section{BAHAN DAN METODE}

\section{Alat dan Bahan}

Bahan yang digunakan adalah tungau merah, kumbang predator Oligota sp., kantong plastik, kapas, kertas label, dan bibit ubikayu. Sedangkan alat yang digunakan antara lain pinset, cawan petri, kotak pemeliharaan serangga, kuas serangga, dan mikroskop stereo.

\section{Metode Penelitian}

\section{Persiapan tanaman inang dan tungau merah}

Survei dilaksanakan pada pertanaman ubikayu di sekitar Bogor. Penelitian biologi dan pemangsaan dilaksanakan di Laboratorium Bionomi dan Ekologi Serangga, Departemen Proteksi Tanaman, Fakultas Pertanian, Institut Pertanian Bogor.

Tanaman ubikayu digunakan untuk pemeliharaan tungau merah sebagai mangsa kumbang predator. Pada penelitian ini digunakan ubikayu varietas Manggu dan Roti yang banyak ditanam petani. Stek ubikayu kemudian dimasukkan ke dalam wadah plastik berdiameter $\pm 15 \mathrm{~cm}$ berisi air hingga muncul daun. Setelah itu tanaman ubikayu diinfestasi dengan tungau merah dan dibiarkan berkembang. Tungau merah kemudian dijadikan mangsa kumbang predator, baik untuk pemeliharaan maupun perlakuan.

\section{Pemeliharaan kumbang predator (Oligota sp.)}

Kumbang predator yang dikoleksi dari lahan ubikayu di sekitar kampus dipelihara di laboratorium dengan menggunakan tungau merah sebagai mangsa. Kumbang Oligota sp. dipelihara di dalam wadah plastik yang berisi daun ubikayu yang diinfestasi oleh tungau merah. Kumbang predator dipelihara selama beberapa generasi sampai mendapatkan jumlah yang cukup untuk penelitian biologi dan pemangsaan.

\section{Survei kelimpahan predator pada tanaman ubikayu}

Survei dilakukan untuk mengetahui kelimpahan tungau dan serangga predator yang ada di pertanaman ubikayu. Sampel daun yang bergejala tungau diambil dari 25 tanaman contoh yang ditentukan secara acak. Dari setiap tanaman contoh diambil satu daun yang bergejala tungau. Daun dimasukkan kedalam kantong plastik satu per satu dan dibawa ke laboratorium untuk diamati. Predator yang ditemukan kemudian dihitung dan diidentifikasi.

\section{Pengamatan biologi kumbang predator (Oligota sp.)}

Pengamatan biologi dan morfologi dilakukan terhadap 80 telur Oligota sp. yang berumur seragam dan dipelihara serta diamati perkembangannya sampai menjadi imago. Telur dipelihara satu per satu dalam wadah plastik yang berisi daun ubikayu yang diinfestasi tungau merah. Pengamatan perkembangan serangga sejak telur sampai menjadi imago dilakukan setiap 6 jam. Selain biologi, pengamatan morfologi setiap stadia perkembangan kumbang juga dilakukan. Setelah menjadi imago, kumbang predator dipasang-pasangkan dan dipelihara sampai mati. Masa praoviposisi, oviposisi, pasca oviposisi dan jumlah telur yang diletakkan diamati setiap hari sampai kumbang mati.

\section{Pengujian kemampuan pemangsaan kumbang predator (Oligota sp.)}

Pengujian kemampuan pemangsaan kumbang predator dilakukan menggunakan larva instar tiga. Larva kumbang predator yang telah dipuasakan selama 3 jam kemudian dimasukkan kedalam cawan petri satu per satu. Setiap larva diberi imago tungau merah dengan jumlah 5, 10, 15, 20, dan 25. Pengamatan jumlah tungau yang dimangsa dilakukan setiap 3, 6, dan 24 jam. Pada pengujian kemampuan pemangsaan kumbang predator ini dilakukan dengan 10 kali ulangan.

\section{HASIL DAN PEMBAHASAN}

\section{Kelimpahan Oligota sp. di pertanaman ubikayu}

Survei dilakukan untuk mengetahui kelimpahan predator tungau yang ada dilapang. Dari hasil survei, selain kumbang Oligota sp., ditemukan beberapa jenis predator tungau yang berasosiasi dengan tungau merah ubikayu, diantaranya tungau predator, larva lalat Cecidomyiidae, thrips predator., dan larva kumbang Coccinellidae. Predator yang paling banyak ditemukan adalah tungau predator famili Phytoseiidae. Selain tungau predator, yang juga banyak ditemukan adalah larva Cecidomyiidae, yang ditemukan 
hampir di seluruh lokasi pengamatan, walaupun jumlahnya masih lebih sedikit dibandingkan dengan tungau predator.

Dari Gambar 1 menggambarkan kondisi populasi kumbang predator Oligota sp. pada pertanaman ubikayu di lokasi survei. Survei dilakukan di 10 pertanaman ubikayu dengan varietas Manggu dan Roti. Kedua varietas tersebut banyak ditanam petani karena selain bisa menghasilkan pati, juga bisa dikonsumsi langsung untuk kebutuhan sehari-hari.

Gambar 1 menunjukkan bahwa hampir semua stadia perkembangan Oligota sp. bisa ditemukan di lapangan. Telur Oligota sp. ditemukan di 6 lokasi, larva di 3 lokasi, sedangkan imago di 2 lokasi. Dari hasil survei juga diketahui bahwa populasi kumbang Oligota sp. di lapangan masih sangat rendah sehingga perannya sebagai agens pengendalian hayati tungau masih belum optimal. Upaya peningkatan populasi kumbang predator ini di lapangan akan bisa meningkatkan perannya dalam mengendalikan tungau hama.

\section{Biologi dan siklus hidup kumbang predator Oligota sp.}

Setiap makhluk hidup mempunyai ciri diantaranya melestarikan keturunannya karena memiliki kemampuan untuk bereproduksi. Kumbang Oligota sp. bereproduksi dengan cara bertelur. Telur berukuran $\pm 0.29 \mathrm{~mm}$, berbentuk lonjong dan berwarna kekuningan. Telur diletakkan di permukaan bawah daun ubikayu secara terpisah-pisah. Telur yang telah diletakkan ditutupi dengan sisa-sisa tungau yang telah dimakan kumbang predator. Rata-rata lama perkembangan stadia telur sampai menjadi larva instar 1 pada jantan selama 2.171 hari dan betina 2.073 hari.

Larva dari kumbang Oligota sp. terdiri dari 3 instar. Setiap instar mempunyai perbedaan karakter dan morfologi. Instar 1 berukuran panjang $\pm 0.75 \mathrm{~mm}$ dan berwarna transparan. Selain itu larva instar 1 cenderung mengkonsumsi telur dari tungau sampai mengalami proses ganti kulit. Rata-rata lama perkembangan dari larva instar 1 pada jantan selama 1.541 hari dan betina 1.597 hari. Larva instar 2 berukuran panjang $\pm 1.25 \mathrm{~mm}$ dan berwarna kuning transparan. Rata-rata lama perkembangan larva instar 2 pada jantan 1.612 hari dan betina 1.589 hari. Larva instar 2 sudah mulai mengkonsumsi tungau namun dalam jumlah yang sedikit. Larva instar 3 berukuran $\pm 1.5 \mathrm{~mm}$ dan berwarna kuning. Rata-rata lama perkembangan larva instar 3 pada jantan 1.763 hari dan betina 1.790 hari. Larva instar 3 lebih aktif bergerak untuk mencari mangsa selain itu larva mengkonsumsi tungau dalam jumlah yang banyak. Dari ketiga tahap perkembangan larva tersebut tidak ada perbedaan yang terlalu jauh antara jantan dan betina dengan rata-rata perkembangan selama 1 hari. Dari pengamatan yang dilakukan terhadap ke-tiga instar larva tidak terjadi kematian.

Setelah tahap instar 3 larva akan menjadi pupa. Namun sebelum mencapai tahap pupa, kumbang akan mengalami fase prapupa. Pada tahap ini kumbang tidak makan dan berdiam diri selama beberapa hari sampai menjadi pupa. Jika proses prapupa tidak berhasil larva tidak menjadi pupa melainkan akan mati dan tubuhnya berubah warna menjadi hitam. Dalam pengamatan yang dilakukan banyak larva yang mati saat proses prapupa. Untuk rata-rata proses prapupa pada jantan 1.783 hari dan betina 1.831 hari. Pupa Oligota sp. berbentuk eksarata, berwarna kuning dan melekat pada permukaan bawah daun, selain itu pupa juga diselimuti oleh benang-benang berwarna putih disekitar pupa namun ada sebagian pupa yang tidak diselimuti oleh benang-benang. Setelah beberapa hari pupa akan berubah warna menjadi hitam. Pupa yang sudah berubah warna menjadi hitam menandakan bahwa pupa tersebut akan menjadi imago. Rata-rata perkembangan pupa jantan selama 6.178 hari dan betina 7.218 hari. Menurut penelitian Chazeau (1985), untuk spesies O. oviformis larva instar 3 yang akan menjadi pupa akan menjatuhkan diri ketanah sehingga kumbang predator ini akan berpupa di tanah. Siklus hidup Oligota sp. mencapai 15.047 hari (jantan) dan 16.097 hari (betina).

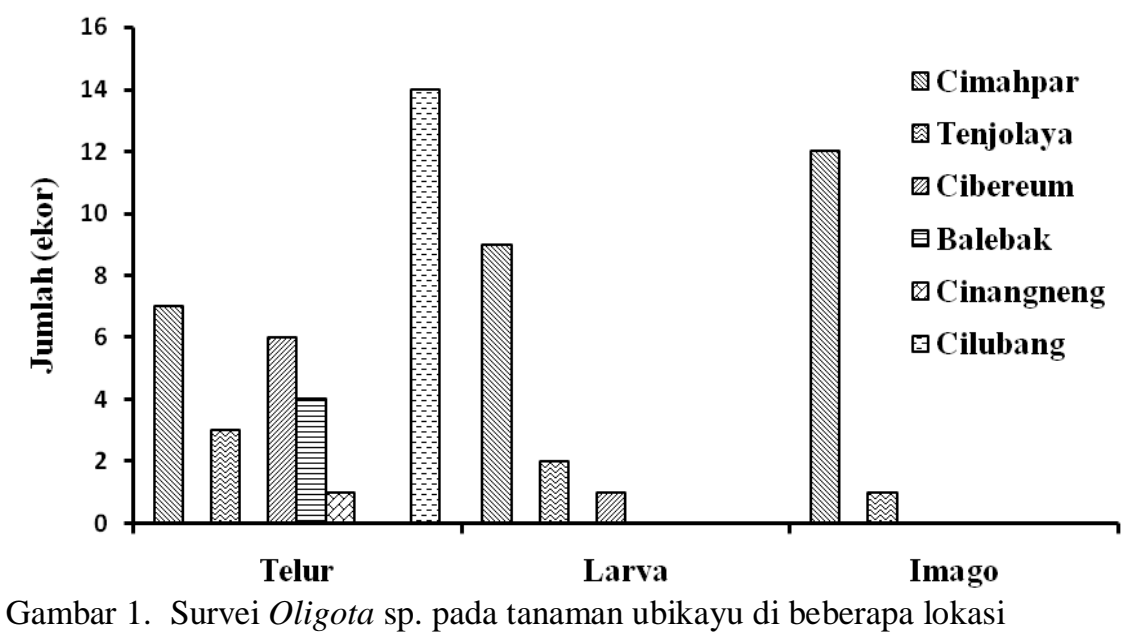

Widyantoro Cahyo Setiawan, dan Sugeng Santoso 
Tabel 1. Lama perkembangan pradewasa Oligota sp.

\begin{tabular}{lcc}
\hline Stadia & \multicolumn{2}{c}{$\begin{array}{c}\text { Lama perkembangan (hari) } \\
\text { (rata-rata } \pm \text { sd) }\end{array}$} \\
\cline { 2 - 3 } Telur & Jantan & $2.073 \pm 0.383$ \\
Larva 1 & $2.171 \pm 0.424$ & $1.597 \pm 0.221$ \\
Larva 2 & $1.541 \pm 0.206$ & $1.589 \pm 0.285$ \\
Larva 3 & $1.612 \pm 0.264$ & $1.790 \pm 0.259$ \\
Prapupa & $1.763 \pm 0.284$ & $1.831 \pm 0.332$ \\
Pupa & $1.783 \pm 0.335$ & $7.218 \pm 1.969$ \\
Total & $6.178 \pm 1.945$ & 16.097 \\
\hline
\end{tabular}

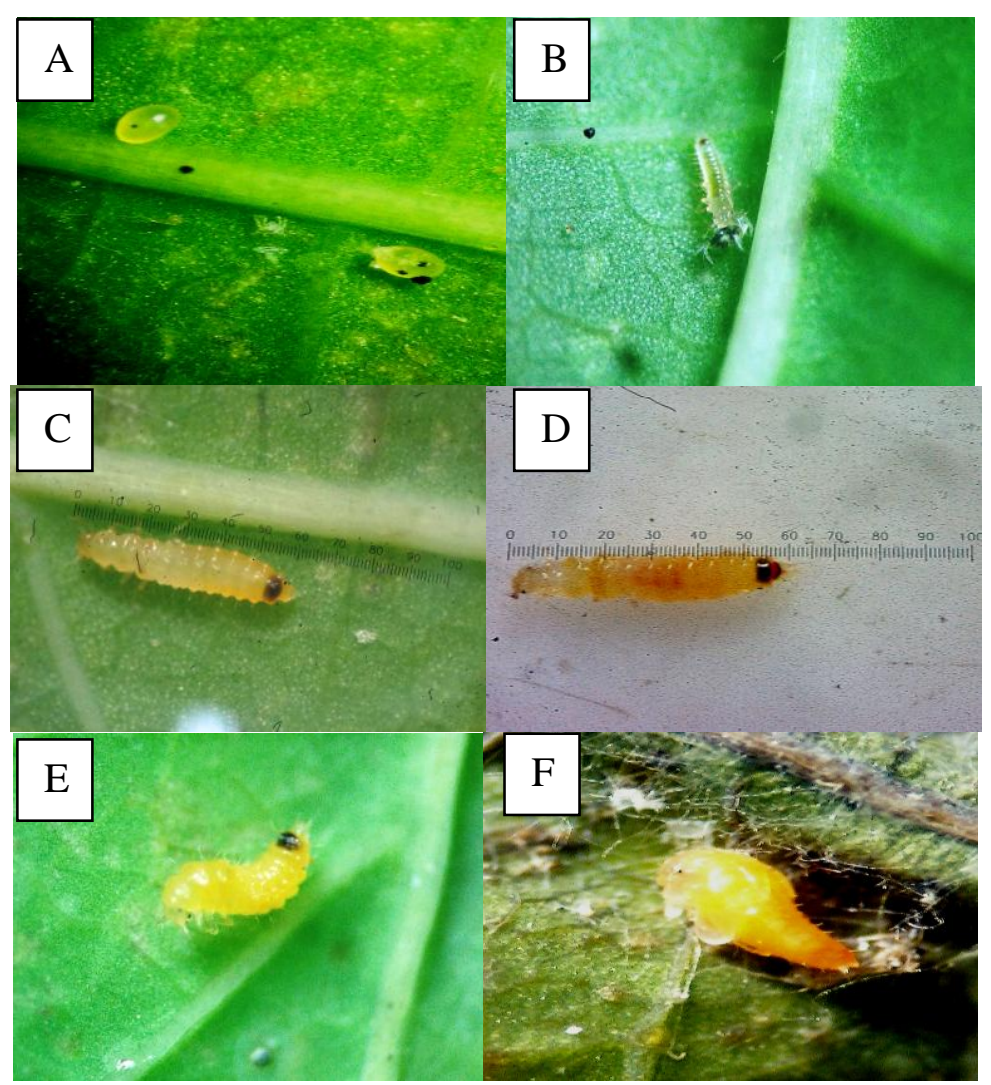

Gambar 2. Fase perkembangan kumbang predator Oligota sp. (A) Telur Oligota sp. (B) larva instar 1 (C) larva instar 2 (D) larva instar $3(\mathrm{E})$ prapupa (F) pupa

Imago dari Oligota sp. berukuran $\pm 1 \mathrm{~mm}$ dan berwarna hitam. Imago Oligota sp. memiliki sayap sehingga dapat terbang dari tanaman satu ke tanaman yang lainnya untuk mencari mangsa yang lebih banyak. Imago dari Oligota sp. memiliki ciri khas yaitu saat berjalan abdomen bagian belakang akan berdiri ke atas ataupun saat dalam keadaan diam bahkan untuk imago jantan ujung abdomen dapat melengkung sampai menyentuh bagian toraks depan yang membedakan dengan imago betina. Bentuk imago betina bulat dan besar, sedangkan jantan cenderung lonjong dan panjang. Imago jantan berwarna hitam mengkilap dan imago betina berwarna keabu-abuan. Selain itu ukuran dari imago jantan lebih kecil dibanding dengan imago betina (Gambar 3). Imago betina dari Oligota sp. memiliki tingkat predasi terhadap tungau Oligonychus coffeae lebih tinggi daripada imago jantan dipertanaman teh (Perumalsamy 2009). Imago betina lebih rakus dalam memangsa tungau dibandingkan dengan larva instar 3 (Shimoda et al. 1993). 
Tabel 2. Sifat biologi imago Oligota sp.

\begin{tabular}{lc}
\hline Periode & Masa keperidian (hari) (rata-rata \pm sd) \\
\hline Masa praoviposisi & $2.692 \pm 1.601$ \\
Masa oviposisi & $14.154 \pm 3.184$ \\
Masa pascaoviposisi & $4.077 \pm 1.038$ \\
Keperidian & $22.923 \pm 13.726$ \\
Jantan & $20.974 \pm 3.360$ \\
Betina & $21.677 \pm 3.156$ \\
\hline
\end{tabular}

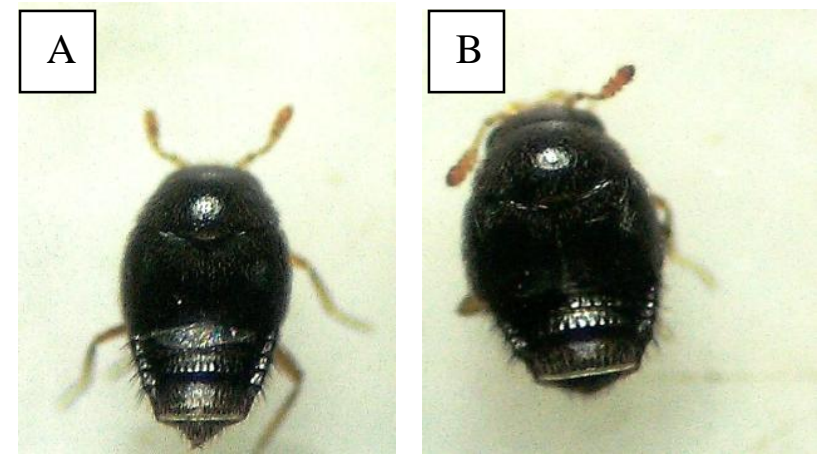

Gambar 3. Imago Oligota sp. (A) Imago jantan (B) imago betina

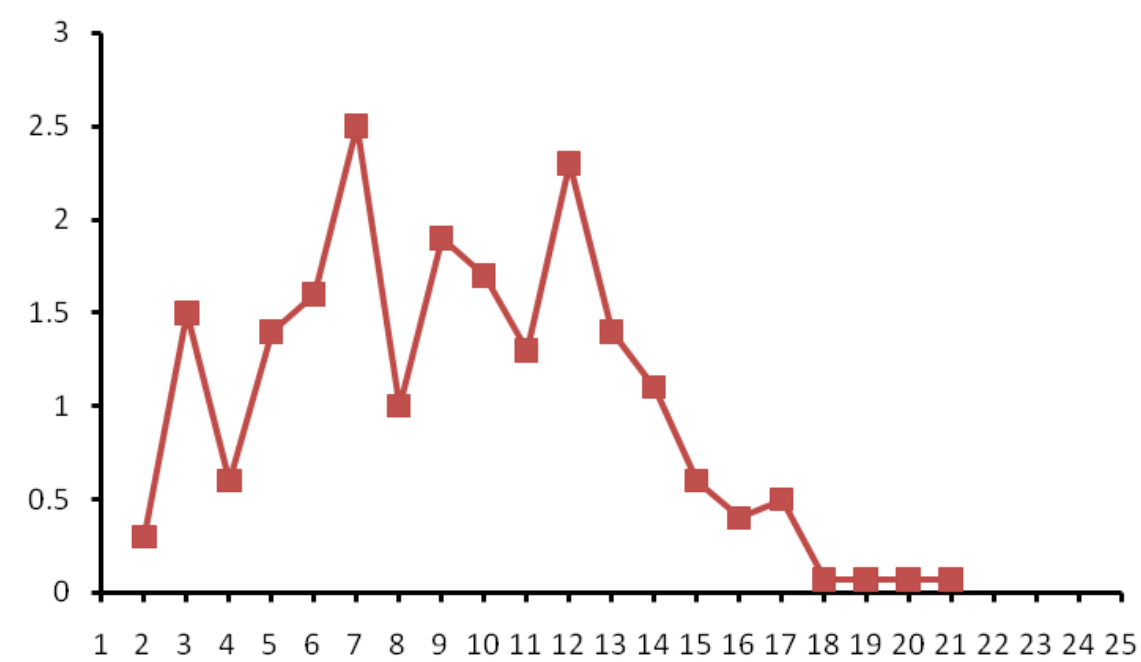

Gambar 4. Peletakan telur harian imago Oligota sp.

Menurut Frank et al. (1992) telah ditemukan imago Oligota di Florida dengan spesies Oligota minuta. Imago Oligota minuta dan larvanya diketahui sebagai predator berbagai macam tungau Tetranychidae pada berbagai tanaman.

Imago jantan dapat hidup selama 20.974 hari dan betina 21.677 hari. Imago jantan yang melakukan perkawinan mempunyai lama hidup yang lebih pendek dibanding dengan yang tidak melakukan perkawinan. Imago betina membutuhkan mangsa dalam jumlah banyak selama proses peneluran. Perkawinan imago jantan dan betina membutuhkan waktu \pm 10 menit dan dalam sehari perkawinan dapat terjadi lebih dari satu kali. Keperidian imago betina rata-rata 22.923 telur. Imago betina memerlukan masa praoviposisi selama 2.692 hari. Masa oviposisi berlangsung selama 14.154 hari, dan masa pasca oviposisi 4.077 hari.

Gambar 4 menunjukkan rata-rata peletakan telur harian betina imago Oligota sp. Pada hari ketujuh jumlah telur yang diletakkan mencapai puncaknya. Selama proses peneluran, imago tidak selalu bertelur setiap hari, bahkan bisa tidak bertelur lebih dari satu hari. Pada hari ke 21, jumlah telur yang diletakkan sangat sedikit. Pada hari ke 22 imago masuk pada tahap pascaoviposisi yaitu imago sudah berhenti bertelur. 


\section{Predasi Oligota sp. terhadap tungau pada waktu 3 jam}
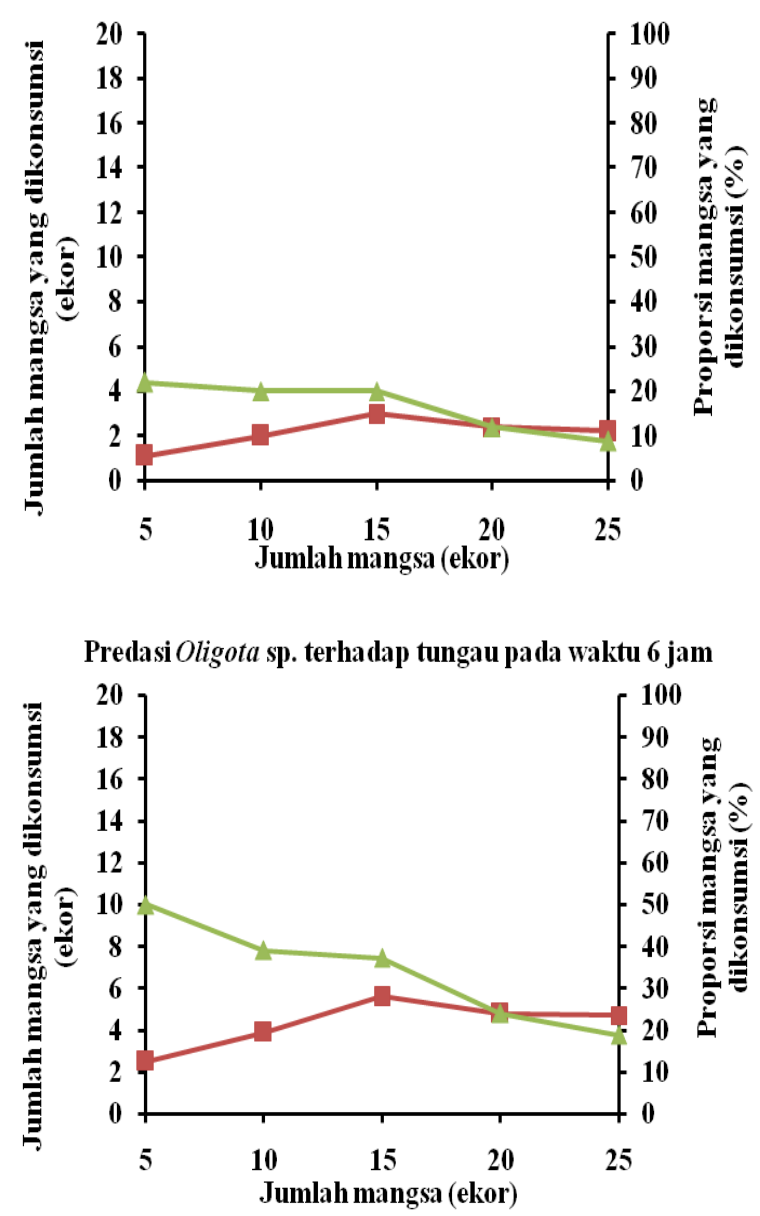

Predasi Oligota sp. terhadap tungau pada waktu 24 jam

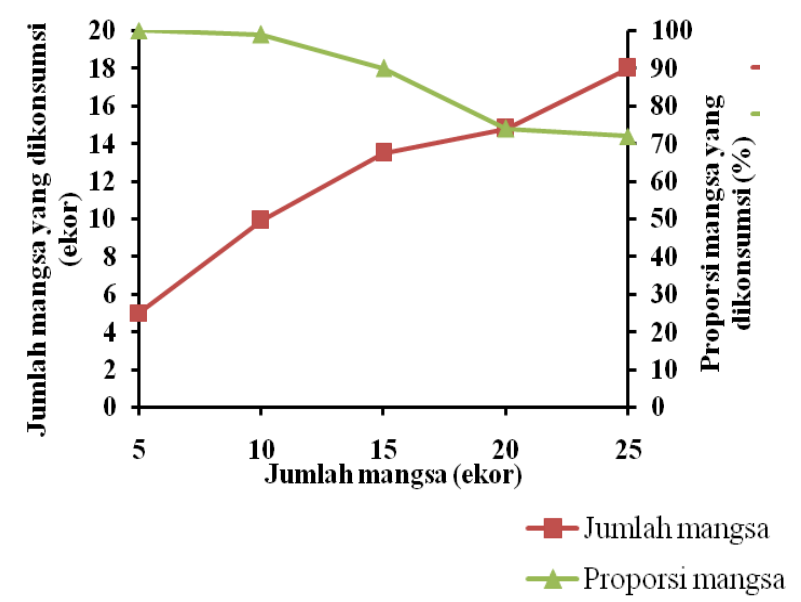

Gambar 5. Tanggap fungsional Oligota sp. terhadap $T$. kanzawai.

\section{Kemampuan pemangsaan larva Oligota sp. terhadap tungau merah ubikayu}

Pengujian kemampuan predasi dilakukan untuk mengetahui seberapa besar kumbang Oligota sp. dalam mengurangi populasi tungau di lapangan. Pengujian kemampuan predasi menggunakan larva instar 3 yang sebelumnya dipuasakan selama 3 jam. Menurut penelitian Shimoda et al. (1997) menunjukkan bahwa larva instar tiga dari Oligota sp. memiliki tingkat predasi yang lebih tinggi dibandingkan larva instar 1 terhadap Tetranychus urticae, karena larva instar ketiga lebih aktif bergerak dibandingkan larva instar satu dan memiliki kemampuan menangkap mangsa (tungau) yang juga aktif bergerak. Pada gambar 5 disajikan kurva pengujian predasi larva Oligota sp. dalam memangsa tungau pada waktu 3, 6, dan 24 jam.

Pada 3 jam setelah perlakuan, tingkat predasi tertinggi adalah 3 ekor, sedangkan yang terendah adalah 1.1 ekor. Pada pengamatan 6 jam setelah perlakuan, jumlah tertinggi mangsa yang dikonsumsi 5.6 ekor, sedangkan pada 24 jam setelah perlakuan kumbang Oligota sp. bisa memangsa rata-rata 18 ekor. Gambar 5 juga menunjukkan bahwa dengan meningkatnya jumlah mangsa yang diberikan, maka jumlah mangsa yang dikonsumsi cenderung meningkat. Semakin lama waktu pemangsaan, maka semakin banyak mangsa yang dikonsumsi. Semakin banyak jumlah mangsa yang diberikan, proporsi mangsa yang dikonsumsi cenderung semakin menurun.

\section{KESIMPULAN}

Kumbang predator Oligota sp. ditemukan berasosiasi dengan tungau merah ubikayu. Kumbang ini memiliki 3 instar, dengan siklus hidup 15.047 hari (jantan), dan 16.097 hari (betina). Imago betina bisa hidup selama 21.677 hari, dan bisa meletakkan 22.923 telur selama 14.154 hari oviposisi. Larva instar 3 Oligota sp. dapat memangsa 18 imago betina tungau merah ubikayu selama 24 jam. Semakin tinggi kepadatan populasi mangsa, semakin meningkat jumlah mangsa yang dikonsumsi. Perlu dilakukan penelitian lebih lanjut tentang kemampuan predasi kumbang Oligota sp. di lapangan. Selain itu perlu adanya penelitian tentang pembiakan masal kumbang predator Oligota sp.

\section{DAFTAR PUSTAKA}

[BPS] Badan Pusat Statistik RI. 2012. Tabel luas panenproduksi tanaman ubi kayu Provinsi Indonesia [Internet]. [diunduh 2012 Nov 26]. Tersedia pada: http://www.bps.go.id/tnmn_pgn.php.

Chazeau, J. 1985. Predaceous insec. Di dalam: Helle W, Sabelis MW, editor. Spider Mites. Their Biology, Natural Enemies and Control. Amsterdam (NL): Elsevier Science Publisher. hlm: 211-246.

Ehara, S, T. Gotoh. 2000. Colored Guide to the Phytophagous Mites of Japan and Their Natural Enemies. Tokyo (JP): Nissan Chemical industry.

Frank, J.H., F.D. Bennett, H.L. Cromroy. 1992. Distribution and prey records for Oligota minuta (Coleoptera: Staphylinidae), a predator of mites. Florida Entomol. 75(3):376-379. 
Hafsah, M.J. 2003. Bisnis Ubi Kayu Indonesia. Jakarta (ID): Pustaka Sinar Harapan.

Kusumastuti, C.T. 2007. Singkong sebagai salah satu sumber bahan bakar nabati (BBN) [Skripsi]. Yogyakarta (ID): Universitas Gajah Mada.

Perumalsamy, K. 2009. Life table and predation of Oligota pygmaea (Coleoptera: Staphylinidae) a major predator of the red spider mite, Oligonychus coffeae (Acarina: Tetranychidae) infesting tea. Bio Control. 51 (1):96-101.

Shimoda, T., N. Shinkaji, H. Amano. 1997. Prey stage preference and feeding behavior of Oligota kashmirica benefica (Coleoptera: Staphylinidae), an insect predator of the spider mite Tetranychus urticae (Acari: Tetranychidae). Experiment Appl Acarology. 21(1):665-675. 